\title{
PPAR Medicines and Human Disease: The ABCs of It All
}

\author{
Anthony J. Apostoli ${ }^{1,2}$ and Christopher J. B. Nicol ${ }^{1,2,3}$ \\ ${ }^{1}$ Department of Pathology and Molecular Medicine, Queen's University, Kingston, ON, Canada K7L 3N6 \\ ${ }^{2}$ Cancer Biology and Genetics Division, Cancer Research Institute, Queen's University, Kingston, ON, Canada K7L 3N6 \\ ${ }^{3}$ Department of Biomedical and Molecular Sciences, Queen's University, Kingston, ON, Canada K7L 3N6
}

Correspondence should be addressed to Christopher J. B. Nicol, nicolc@queensu.ca

Received 24 February 2012; Revised 4 April 2012; Accepted 6 April 2012

Academic Editor: Yuji Kamijo

Copyright ( $) 2012$ A. J. Apostoli and C. J. B. Nicol. This is an open access article distributed under the Creative Commons Attribution License, which permits unrestricted use, distribution, and reproduction in any medium, provided the original work is properly cited.

\begin{abstract}
ATP-dependent binding cassette $(\mathrm{ABC})$ transporters are a family of transmembrane proteins that pump a variety of hydrophobic compounds across cellular and subcellular barriers and are implicated in human diseases such as cancer and atherosclerosis. Inhibition of $\mathrm{ABC}$ transporter activity showed promise in early preclinical studies; however, the outcomes in clinical trials with these agents have not been as encouraging. Peroxisome proliferator-activated receptors (PPARs) are ligand-activated transcription factors that regulate genes involved in fat and glucose metabolism, and inflammation. Activation of PPAR signaling is also reported to regulate $\mathrm{ABC}$ gene expression. This suggests the potential of PPAR medicines as a novel means of controlling ABC transporter activity at the transcriptional level. This paper summarizes the advances made in understanding how PPAR medicines affect $\mathrm{ABC}$ transporters, and the potential implications for impacting on human diseases, in particular with respect to cancer and atherosclerosis.
\end{abstract}

\section{Introduction}

Harnessing the energy released from adenosine triphosphate (ATP) hydrolysis, ATP-dependent binding cassette (ABC) transporters shuttle a wide range of substrates, including lipids, metabolites, and xenobiotics, across biological membranes in order to maintain normal cell metabolism. They represent the largest family of transmembrane proteins in humans, comprising $49 \mathrm{ABC}$ genes, and are best reviewed elsewhere [1-3]. These genes are subdivided among seven subfamilies (A-G) based on sequence and structural homology and are highly conserved among eukaryotic species, suggesting that most appeared early in metazoan evolution [4]. The proteins encoded by $\mathrm{ABC}$ genes consist of two distinct domains: a transmembrane domain that recognizes specific compounds and transports them across cellular and subcellular barriers and a nucleotide-binding domain where ATP hydrolysis occurs to yield energy for substrate transport [5]. Typically, ABC proteins are unidirectional transporters expressed at the cell membrane, which move hydrophobic molecules internally for metabolic pathways, or externally for elimination from the cell and/or use by other tissues and organs. Thus, $\mathrm{ABC}$ transporters play important roles in a range of human physiologic, toxicologic, and pathologic functions. With respect to the latter, many preclinical reports that show promise in terms of regulating $\mathrm{ABC}$ transporters to overcome chemotherapeutic drug resistance in tumours, or modify lipid homeostasis in order to reduce atherosclerotic risk, have not achieved the same level of success in clinical trials.

Peroxisome proliferator-activated receptors (PPARs) are ligand-activated transcription factors that regulate expression of a plethora of genes involved in sugar and fat metabolism, inflammation, and cancer [6-8]. Three PPAR homologs have been characterized-PPAR $\alpha, \operatorname{PPAR} \beta / \delta$, and PPAR $\gamma$ - each displaying a unique pattern of tissue-specific expression that reflect their distinctive functions [9-11]. Recently, there is mounting in vitro and in vivo evidence that activation of PPARs may alter $\mathrm{ABC}$ protein expression and/or function. Accordingly, this paper will summarize recent developments in an emerging field where PPAR medicines, capable of modulating $\mathrm{ABC}$ transporter genes at the transcriptional level, may prove useful when such modulation provides novel therapeutic options for treating cancer and atherosclerosis. 


\section{PPARs and Their Ligands}

As members of the nuclear receptor superfamily, PPARs contain a ligand-binding domain that recognizes and binds specific PPAR agonists, and a DNA-binding domain that interacts with specific peroxisome proliferator-response elements (PPREs) within the genome [12]. PPARs are localized to the nucleus and dimerize with retinoid $X$ receptor $(\mathrm{RXR}) \alpha$ to form complexes that bind to PPREs in the promoter regions of a broad range of target genes [13]. In its resting state, the PPAR:RXR $\alpha$ complex associates with cell-specific corepressor molecules that aid in the silencing of target gene transcription. Ligand binding elicits a conformational change in PPAR that leads to the release of corepressors, and the recruitment of coactivator molecules that promote target gene transcriptional activity. Furthermore, ligand activation of PPARs may also repress signaling of some gene targets through direct interaction with other transcription factors or competition for available coregulators [14].

PPAR $\alpha$ is highly expressed in the liver, heart, kidney, skeletal muscle, and large intestine [15]. It is activated by the "fibrate" class of drugs, such as bezafibrate, ciprofibrate, clofibrate, gemfibrozil, and fenofibrate, used to treat elevated triglycerides and low high-density lipoprotein (HDL) [16]. $\operatorname{PPAR} \beta / \delta$ is more ubiquitously expressed with highest levels noted within the large intestine and placenta [15]. Similar to other PPAR subtypes, it may also be activated by various saturated and unsaturated fatty acids [12]. Because less is understood about $\operatorname{PPAR} \beta / \delta$, fewer synthetic activators have been developed; however, emerging evidence supports the potential therapeutic value of $\mathrm{PPAR} \beta / \delta$ agonists, such as GW0742, GW501516, and MBX-8025, which remain to be clinically tested [17].

As a chief regulator of adipogenesis, PPAR $y$ is abundantly expressed in adipose tissue [18], and like PPAR $\alpha$, is also detected in vascular and immune cells, as well as tissues such as the colon, breast, and prostate $[19,20]$. Synthetic agents known as thiazolidinediones (TZDs) like troglitazone, ciglitazone, rosiglitazone, and pioglitazone are classic examples of PPAR $\gamma$ activators [21]. In North America, rosiglitazone and pioglitazone are still prescribed to treat type 2 diabetic patients. However, there are reports suggesting increased myocardial infarction risk with rosiglitazone use and bladder cancer risk with long-term use of pioglitazone [22, 23]. As a followup on the former, a safety review of rosiglitazone by a panel of international experts deemed the available data inconclusive and requiring further study. In the latter case, direct clinical evidence of this possible association is also required. Despite the need for more evidence, these drugs remain FDA approved, albeit with warning updates to package inserts clarifying the potential for risk [24, 25], and a Risk Evaluation and Mitigation Strategy (REMS) is in place to restrict access and distribution of rosiglitazonecontaining medicines to those healthcare providers and their patients who confirm their awareness of the new warnings [26]. Nevertheless, the utility of these drugs remains valuable not only for their ability to provide mechanistic insight into the role of PPAR $\gamma$-mediated target regulation, but also for their potential benefit in certain off-label uses.
Dual and pan PPAR ligands were also developed to enhance therapeutic potential via simultaneously activating two or more PPAR isoforms. Examples include PPAR $\alpha / \gamma$ modulators like tesaglitazar, muraglitazar, and aleglitazar, and the pan $\operatorname{PPAR} \alpha /(\beta / \delta) / \gamma$ agonist chiglitazar [27].

The reported links between the above listed PPAR medicines and their in vitro and in vivo effects on $\mathrm{ABC}$ transporters are summarized in Tables 1 and 2, respectively, and described in detail below in the context of several human diseases.

\section{Cancer}

The goal of chemotherapy is to target rapidly dividing cells or deregulated signaling pathways to suppress tumour growth, and ultimately, cure cancer patients; however, one primary roadblock to the success of chemotherapy is acquisition of multidrug resistance (MDR). A well-known cause of MDR is $A B C$ transporter-driven drug efflux from cancer cells instilling resistance to multiple agents [28]. The well-known $A B C$ transporters, P-glycoprotein (Pgp)/MDR1/ABCB1, multidrug resistance protein (MRP) 1/ABCC1, and breast cancerresistance protein (BCRP)/MXR/ABCG2, are overexpressed in a variety of different human cancers and transport a range of chemotherapeutic drugs [4]. Pgp, an important blood brain barrier component and regulator of intestinal drug absorption, was the first $\mathrm{ABC}$ transporter to be characterized in 1976 [29]. Its overexpression in tumours of the kidney, liver, colon, and breast correlates with chemoresistance [30-32]. Substrates of Pgp include anthracyclines, vinca alkaloids, taxanes, camptothecins, mitoxantrone, and methotrexate [33]. The second $\mathrm{ABC}$ gene discovered was the more ubiquitously expressed MRP1 [34], which transports anthracyclines, vinca alkaloids, and etoposide, in addition to organic anions and glutathione conjugates [28]. Its overexpression confers chemotherapy resistance in prostate, lung, breast, and neuroblastoma cancer $[35,36]$. Finally, BCRP is normally expressed in placenta and small intestine, as well as various stem cell populations $[37,38]$. Several drug-resistant cell lines also contain elevated levels of this $A B C$ transporter, which contributes to the efflux of several antitumour agents such as doxorubicin, daunorubicin, mitoxantrone, and topotecan [39-41].

In addition to $\mathrm{MDR}$, other functions of $\mathrm{ABC}$ transporters in cancer are beginning to emerge, further implicating these genes as important targets of chemotherapy. For example, Pgp expression, devoid of ATP-dependent drug transport, suppresses cell death in the presence of apoptotic signals in normal and cancer cells [42-44]. Furthermore, Pgp knockdown reduced the migration and invasion potential of MCF7 human breast cancer cells [45]. As a result of these studies, direct inhibition of $\mathrm{ABC}$ transporter activity has become an appealing undertaking for researchers in the development of improved cancer chemotherapeutics; however, several clinical trials using ABC inhibitors have proven unsuccessful [46].

Research has shown that PPAR activation induces expression of both mouse (Mdr1/Mdr1b/Abcb1b, Mdr2/ Abcb4, and Mdr3/Mdrla/Abcbla) and human (MDR2/ MDR3/ABCB4) homologs of Pgp, which efflux similar 
TABLE 1: In vitro effects of PPAR ligands on ABC transporters.

\begin{tabular}{|c|c|c|c|c|c|}
\hline $\mathrm{ABC}$ transporter & PPAR & PPAR Ligand & Cell line & Transporter effect & Reference \\
\hline \multirow[t]{36}{*}{$A B C A 1$} & $\operatorname{PPAR} \alpha$ & Bezafibrate & Primary mouse fibroblasts & $\uparrow \mathrm{ABCA} 1$ and $\mathrm{LXR} \alpha \mathrm{mRNA}$ & {$[47]$} \\
\hline & & & THP1 human macrophages & $\uparrow$ apoA1-mediated cholesterol efflux & \\
\hline & & & WI38 human fibroblasts & & \\
\hline & & & Immortalized human mesangial cells & $\uparrow \mathrm{ABCA} 1$ and $\mathrm{LXR} \alpha$ mRNA & {$[48]$} \\
\hline & & & & $\uparrow$ apoA1-mediated cholesterol efflux & \\
\hline & & & Primary mouse hepatocytes & $\uparrow \mathrm{ABCA} 1 \mathrm{mRNA}$ and protein & [49] \\
\hline & & & HepG2 human hepatoma cells & $\uparrow$ HDL synthesis & \\
\hline & & Clofibrate & Primary human foreskin keratinocytes & $\uparrow$ ABCA1 mRNA & {$[50]$} \\
\hline & & Fenofibrate & Primary mouse fibroblasts & $\uparrow \mathrm{ABCA} 1$ and $\mathrm{LXR} \alpha$ mRNA & {$[47]$} \\
\hline & & & THP1 human macrophages & $\uparrow$ apoA1-mediated cholesterol efflux & \\
\hline & & & WI38 human fibroblasts & & \\
\hline & & & BALB/3T3 mouse fibroblasts & $\uparrow \mathrm{ABCA} 1 \mathrm{mRNA}$ and protein & {$[51]$} \\
\hline & & & $\begin{array}{l}\text { RAW264.7 mouse leukemic } \\
\text { macrophages }\end{array}$ & $\uparrow$ apoA1-mediated cholesterol efflux & \\
\hline & & & THP1 human macrophages & & \\
\hline & & & Primary mouse hepatocytes & $\uparrow \mathrm{ABCA} 1 \mathrm{mRNA}$ and protein & [49] \\
\hline & & & HepG2 human hepatoma cells & $\uparrow$ HDL synthesis & \\
\hline & & Gemfibrozil & Primary mouse fibroblasts & $\uparrow \mathrm{ABCA} 1$ and $\mathrm{LXR} \alpha$ mRNA & {$[47]$} \\
\hline & & & THP1 human macrophages & $\uparrow$ apoA1-mediated cholesterol efflux & \\
\hline & & & WI38 human fibroblasts & & \\
\hline & & & Primary mouse hepatocytes & $\uparrow \mathrm{ABCA} 1 \mathrm{mRNA}$ and protein & [49] \\
\hline & & & HepG2 human hepatoma cells & $\uparrow \mathrm{HDL}$ synthesis & \\
\hline & & LY518674 & Primary mouse fibroblasts & $\uparrow \mathrm{ABCA} 1$ and $\mathrm{LXR} \alpha$ mRNA & {$[47]$} \\
\hline & & & THP1 human macrophages & $\uparrow$ apoA1-mediated cholesterol efflux & \\
\hline & & & WI38 human fibroblasts & & \\
\hline & & & Primary mouse hepatocytes & $\uparrow \mathrm{ABCA} 1 \mathrm{mRNA}$ and protein & {$[49]$} \\
\hline & & & HepG2 human hepatoma cells & $\uparrow \mathrm{HDL}$ synthesis & \\
\hline & & RPR-5 & Primary human macrophages & $\uparrow \mathrm{ABCA} 1$ and $\mathrm{LXR} \alpha$ mRNA & {$[52]$} \\
\hline & & WY14643 & Immortalized human mesangial cells & $\uparrow \mathrm{ABCA} 1$ and $\mathrm{LXR} \alpha$ mRNA & {$[48]$} \\
\hline & & & & $\uparrow$ apoA1-mediated cholesterol efflux & \\
\hline & & & Primary human macrophages & $\uparrow \mathrm{ABCA} 1$ and $\mathrm{LXR} \alpha$ mRNA & {$[52]$} \\
\hline & & & & $\uparrow$ apoA1-mediated cholesterol efflux & \\
\hline & & & THP1 human macrophages & $\uparrow \mathrm{ABCA} 1 \mathrm{mRNA}$ & {$[52]$} \\
\hline & & & $\mathrm{BALB} / 3 \mathrm{~T} 3$ mouse fibroblasts & $\uparrow \mathrm{ABCA} 1 \mathrm{mRNA}$ and protein & {$[51]$} \\
\hline & & & $\begin{array}{l}\text { RAW264.7 mouse leukemic } \\
\text { macrophages }\end{array}$ & $\uparrow$ apoA1-mediated cholesterol efflux & \\
\hline & & & THP1 human macrophages & & \\
\hline & & & $\begin{array}{l}\text { Primary canine gallbladder epithelial } \\
\text { cells }\end{array}$ & $\uparrow \mathrm{ABCA} 1 \mathrm{mRNA}$ and protein & {$[53]$} \\
\hline
\end{tabular}


Table 1: Continued.

\begin{tabular}{|c|c|c|c|c|c|}
\hline $\mathrm{ABC}$ transporter & PPAR & PPAR Ligand & Cell line & Transporter effect & Reference \\
\hline & $\operatorname{PPAR} \alpha / \gamma$ & 13-HODE & $\begin{array}{l}\text { RAW264.7 mouse leukemic } \\
\text { macrophages }\end{array}$ & $\begin{array}{l}\uparrow \text { Abcal and LXR } \alpha \text { protein } \\
\uparrow \text { cholesterol efflux }\end{array}$ & {$[54]$} \\
\hline & & $c 9 t 11-\mathrm{CLA}$ & $\begin{array}{l}\text { RAW264.7 mouse leukemic } \\
\text { macrophages }\end{array}$ & $\begin{array}{l}\uparrow \text { Abcal mRNA and protein } \\
\uparrow \text { LXR } \alpha \text { mRNA } \\
\uparrow \text { HDL-mediated cholesterol efflux }\end{array}$ & {$[55]$} \\
\hline & & t10c12-CLA & $\begin{array}{l}\text { RAW264.7 mouse leukemic } \\
\text { macrophages }\end{array}$ & $\begin{array}{l}\uparrow \text { Abcal mRNA and protein } \\
\uparrow \mathrm{LXR} \alpha \text { mRNA } \\
\uparrow \text { HDL-mediated cholesterol efflux }\end{array}$ & {$[55]$} \\
\hline & & NO-pravastatin & $\begin{array}{l}\text { Primary canine gallbladder epithelial } \\
\text { cells }\end{array}$ & $\begin{array}{l}\uparrow \mathrm{ABCA} 1 \mathrm{mRNA} \text { and protein } \\
\uparrow \mathrm{LXR} \alpha \mathrm{mRNA}\end{array}$ & {$[53]$} \\
\hline & & Pravastatin & $\begin{array}{l}\text { Primary canine gallbladder epithelial } \\
\text { cells }\end{array}$ & $\begin{array}{l}\uparrow \text { ABCA } 1 \text { mRNA and protein } \\
\uparrow \mathrm{LXR} \alpha \text { mRNA }\end{array}$ & {$[53]$} \\
\hline & & Simvastatin & $\begin{array}{l}\text { Primary canine gallbladder epithelial } \\
\text { cells }\end{array}$ & $\begin{array}{l}\uparrow \mathrm{ABCA} 1 \mathrm{mRNA} \text { and protein } \\
\uparrow \mathrm{LXR} \alpha \mathrm{mRNA}\end{array}$ & {$[53]$} \\
\hline & $\operatorname{PPAR} \gamma$ & Pioglitazone & $\begin{array}{l}\text { Primary mouse fibroblasts } \\
\text { THP1 human macrophages } \\
\text { WI38 human fibroblasts }\end{array}$ & $\begin{array}{l}\uparrow \text { ABCA1 and LXR } \alpha \text { mRNA } \\
\uparrow \text { apoA1-mediated cholesterol efflux }\end{array}$ & {$[47]$} \\
\hline & & & $\begin{array}{l}\text { RAW264.7 mouse leukemic } \\
\text { macrophages } \\
\text { THP1 human macrophages }\end{array}$ & $\begin{array}{l}\uparrow \text { Abca } 1 \text { mRNA and protein } \\
\uparrow \text { cholesterol efflux }\end{array}$ & {$[56]$} \\
\hline & & Rosiglitazone & Primary human macrophages & $\begin{array}{l}\uparrow \mathrm{ABCA} 1 \text { and LXR } \alpha \text { mRNA } \\
\uparrow \text { apoA1-mediated cholesterol efflux }\end{array}$ & {$[52]$} \\
\hline & & & THP1 human macrophages & $\uparrow \mathrm{ABCA} 1 \mathrm{mRNA}$ & {$[52]$} \\
\hline & & & & $\begin{array}{l}\uparrow \text { ABCA } 1 \text { and LXR } \alpha \text { mRNA } \\
\uparrow \text { cholesterol efflux }\end{array}$ & {$[57]$} \\
\hline & & & & $\uparrow \mathrm{ABCA} 1 \mathrm{mRNA}$ and protein & {$[58]$} \\
\hline & & & & $\begin{array}{l}\uparrow \text { ABCA1 mRNA and protein } \\
\downarrow \text { intracellular cholesterol }\end{array}$ & {$[59]$} \\
\hline & & Troglitazone & Primary human macrophages & $\uparrow \mathrm{ABCA} 1$ and $\mathrm{LXR} \alpha$ mRNA & {$[52]$} \\
\hline & & & THP1 human macrophages & $\uparrow \mathrm{ABCA} 1 \mathrm{mRNA}$ & {$[52]$} \\
\hline & & & $\begin{array}{l}\text { Primary canine gallbladder epithelial } \\
\text { cells }\end{array}$ & $\uparrow \mathrm{ABCA} 1 \mathrm{mRNA}$ and protein & {$[53]$} \\
\hline & & GW1929 & HepG2 human hepatoma cells & $\begin{array}{l}\uparrow \mathrm{ABCA} 1, \mathrm{LXR} \alpha \text {, and LXR } \beta \text { mRNA } \\
\downarrow \mathrm{ABCA} 1 \text { and } \mathrm{LXR} \beta \text { protein }\end{array}$ & {$[60]$} \\
\hline
\end{tabular}


Table 1: Continued.

\begin{tabular}{|c|c|c|c|c|c|}
\hline $\mathrm{ABC}$ transporter & PPAR & PPAR Ligand & Cell line & Transporter effect & Reference \\
\hline & \multirow{10}{*}{$\operatorname{PPAR} \beta / \delta$} & GW7845 & THP1 human macrophages & $\uparrow$ ABCA1 mRNA & {$[61]$} \\
\hline & & $\begin{array}{l}\text { Mycophenolic } \\
\text { acid }\end{array}$ & HepG2 human hepatoma cells & $\begin{array}{l}\uparrow \text { ABCA } 1 \text { mRNA and protein } \\
\uparrow \mathrm{LXR} \alpha \text { protein }\end{array}$ & {$[62]$} \\
\hline & & \multirow[t]{2}{*}{ Prostaglandin J2 } & Immortalized human mesangial cells & $\begin{array}{l}\uparrow \text { ABCA1 and LXR } \alpha \text { mRNA } \\
\uparrow \text { apoA1-mediated cholesterol } \\
\text { efflux }\end{array}$ & {$[48]$} \\
\hline & & & Primary human macrophages & $\uparrow \mathrm{ABCA} 1$ and $\mathrm{LXR} \alpha$ mRNA & {$[52]$} \\
\hline & & Telmisartan & $\begin{array}{l}\text { RAW264.7 mouse leukemic } \\
\text { macrophages }\end{array}$ & $\begin{array}{l}\uparrow \text { Abcal mRNA } \\
\downarrow \text { macrophage proliferation }\end{array}$ & {$[63]$} \\
\hline & & GW501516 & $\begin{array}{l}\text { Primary mouse fibroblasts } \\
\text { THP1 human macrophages } \\
\text { WI38 human fibroblasts }\end{array}$ & $\begin{array}{l}\uparrow \text { ABCA1 and LXR } \alpha \text { mRNA } \\
\uparrow \text { apoA1-mediated cholesterol } \\
\text { efflux }\end{array}$ & {$[47]$} \\
\hline & & & $\begin{array}{l}\text { THP1 human macrophages } \\
\text { 1BR3N human fibroblasts }\end{array}$ & $\begin{array}{l}\uparrow \text { ABCA1 mRNA } \\
\uparrow \text { apoA1-mediated cholesterol } \\
\text { efflux }\end{array}$ & {$[61]$} \\
\hline & & & FHS74 human intestinal cells & $\uparrow \mathrm{ABCA} 1 \mathrm{mRNA}$ & {$[61]$} \\
\hline & & & Primary human skeletal muscle cells & $\uparrow \mathrm{ABCA} 1 \mathrm{mRNA}$ & {$[64]$} \\
\hline & & & Primary human foreskin keratinocytes & $\uparrow \mathrm{ABCA} 1 \mathrm{mRNA}$ & {$[50]$} \\
\hline \multirow[t]{5}{*}{$A B C A 12$} & \multirow[t]{3}{*}{$\operatorname{PPAR} \gamma$} & Ciglitazone & Primary human foreskin keratinocytes & $\uparrow \mathrm{ABCA} 12 \mathrm{mRNA}$ and protein & {$[65]$} \\
\hline & & Troglitazone & Primary human foreskin keratinocytes & $\uparrow \mathrm{ABCA} 12 \mathrm{mRNA}$ & {$[65]$} \\
\hline & & GI251929X & Primary human foreskin keratinocytes & $\uparrow \mathrm{ABCA} 12 \mathrm{mRNA}$ & {$[65]$} \\
\hline & \multirow[t]{2}{*}{$\operatorname{PPAR} \beta / \delta$} & Ceramide & Primary human foreskin keratinocytes & $\uparrow \mathrm{ABCA} 12 \mathrm{mRNA}$ and protein & {$[66]$} \\
\hline & & GW610742 & Primary human foreskin keratinocytes & $\uparrow \mathrm{ABCA} 12 \mathrm{mRNA}$ and protein & {$[65]$} \\
\hline \multirow[t]{6}{*}{$P g p / M D R 1 / A B C B 1$} & $\operatorname{PPAR} \alpha$ & Fenofibrate & $\begin{array}{l}\text { Pgp-overexpressing L-MDR1 porcine } \\
\text { kidney epithelial cells }\end{array}$ & $\downarrow$ calcein efflux & {$[67]$} \\
\hline & $\operatorname{PPAR} \alpha / \gamma$ & Simvastatin & $\begin{array}{l}\text { Pgp-overexpressing L-MDR1 porcine } \\
\text { kidney epithelial cells }\end{array}$ & $\downarrow$ calcein efflux & {$[67]$} \\
\hline & \multirow[t]{4}{*}{$\operatorname{PPAR} \gamma$} & Rosiglitazone & $\begin{array}{l}\text { Doxorubicin-resistant P388 mouse } \\
\text { leukemia cells }\end{array}$ & $\downarrow$ calcein efflux & {$[68]$} \\
\hline & & \multirow[t]{3}{*}{ Troglitazone } & $\begin{array}{l}\text { Doxorubicin-resistant P388 mouse } \\
\text { leukemia cells }\end{array}$ & $\downarrow$ calcein efflux & {$[68]$} \\
\hline & & & $\begin{array}{l}\text { Doxorubicin-resistant K562 human } \\
\text { leukemia cells }\end{array}$ & $\begin{array}{l}\downarrow \text { Pgp protein } \\
\uparrow \text { sensitivity to doxorubicin }\end{array}$ & {$[69]$} \\
\hline & & & $\begin{array}{l}\text { Doxorubicin-resistant MCF7 human } \\
\text { breast cancer cells }\end{array}$ & & \\
\hline
\end{tabular}


Table 1: Continued.

\begin{tabular}{|c|c|c|c|c|c|}
\hline $\mathrm{ABC}$ transporter & PPAR & PPAR Ligand & Cell line & Transporter effect & Reference \\
\hline & & & Vincristine-resistant SGC7901 human & $\downarrow$ Pgp mRNA and protein & {$[70]$} \\
\hline & & & gastric cancer cells & $\downarrow$ Rh123 efflux & \\
\hline & & & & $\uparrow$ sensitivity to vincristine & \\
\hline \multirow[t]{7}{*}{$M D R 2 / M D R 3 / A B C B 4$} & $\operatorname{PPAR} \alpha$ & Bezafibrate & HepG2 human hepatoma cells & $\uparrow \mathrm{MDR} 2 / \mathrm{MDR} 3 \mathrm{mRNA}$ & {$[71]$} \\
\hline & & & & $\uparrow \mathrm{MDR} 2 / \mathrm{MDR} 3$ redistribution & \\
\hline & & & & $\uparrow \mathrm{MDR} 2 / \mathrm{MDR} 3 \mathrm{mRNA}$ & {$[72]$} \\
\hline & & & & $\uparrow \mathrm{MDR} 2 / \mathrm{MDR} 3$ redistribution & \\
\hline & & & & $\uparrow$ phospholipid efflux & \\
\hline & & Ciprofibrate & Primary mouse hepatocytes & $\uparrow \mathrm{Mdr} 2 \mathrm{mRNA}$ & {$[73]$} \\
\hline & & WY14643 & Primary mouse hepatocytes & $\uparrow \mathrm{Mdr} 2 \mathrm{mRNA}$ & {$[73]$} \\
\hline$M R P 2 / A B C C 2$ & PPAR $\gamma$ & Troglitazone & Primary rat hepatocytes & $\downarrow$ Mrp2-associated bile efflux & {$[74]$} \\
\hline \multirow[t]{8}{*}{$A B C G 1$} & $\operatorname{PPAR} \alpha / \gamma$ & 13-HODE & $\begin{array}{l}\text { RAW264.7 mouse leukemic } \\
\text { macrophages }\end{array}$ & $\begin{array}{l}\uparrow \text { Abcg } 1 \text { and } \operatorname{LXR} \alpha \text { protein } \\
\uparrow \text { cholesterol efflux }\end{array}$ & {$[54]$} \\
\hline & $\operatorname{PPAR} \gamma$ & Pioglitazone & RAW264.7 mouse leukemic & $\uparrow \mathrm{ABCG} 1 \mathrm{mRNA}$ and protein & {$[56]$} \\
\hline & & & macrophages & $\uparrow$ cholesterol efflux & \\
\hline & & & THP1 human macrophages & & \\
\hline & & Rosiglitazone & THP1 human macrophages & $\uparrow$ ABCG1 and LXR $\alpha$ mRNA & [57] \\
\hline & & & & $\uparrow$ cholesterol efflux & \\
\hline & & Telmisartan & RAW264.7 mouse leukemic & $\uparrow$ Abcg1 mRNA & {$[63]$} \\
\hline & & & macrophages & $\downarrow$ macrophage proliferation & \\
\hline \multirow[t]{14}{*}{$B C R P / A B C G 2$} & $\operatorname{PPAR} \alpha$ & Clofibrate & HCMEC/D3 human cerebral & $\uparrow \mathrm{BCRP}$ mRNA and protein & {$[75]$} \\
\hline & & & microvascular endothelial cells & $\uparrow$ mitoxantrone efflux & \\
\hline & & GW7647 & $\begin{array}{l}\text { HCMEC/D3 human cerebral } \\
\text { microvascular endothelial cells }\end{array}$ & $\uparrow \mathrm{BCRP}$ mRNA and protein & {$[75]$} \\
\hline & $\operatorname{PPAR} \gamma$ & Rosiglitazone & Primary human dendritic cells & $\uparrow \mathrm{BCRP}$ mRNA and protein & {$[76]$} \\
\hline & & & & $\uparrow$ Hoescht efflux & \\
\hline & & & & $\uparrow$ mitoxantrone efflux & \\
\hline & & & & $\uparrow$ sensitivity to mitoxantrone & \\
\hline & & & $\begin{array}{l}\text { BCRP-overexpressing MDCKII canine } \\
\text { kidney epithelial cells }\end{array}$ & $\downarrow$ PhA efflux & {$[68]$} \\
\hline & & & HuH7 human hepatoma cells & $\uparrow \mathrm{BCRP}$ mRNA & {$[68]$} \\
\hline & & Troglitazone & Primary human dendritic cells & $\uparrow \mathrm{BCRP}$ mRNA & {$[76]$} \\
\hline & & & HuH7 human hepatoma cells & $\uparrow \mathrm{BCRP}$ mRNA & {$[68]$} \\
\hline & & & Doxorubicin-resistant K562 human & $\downarrow$ BCRP protein & [69] \\
\hline & & & leukemia cells & $\uparrow$ sensitivity to doxorubicin & \\
\hline & & & $\begin{array}{l}\text { Doxorubicin-resistant MCF7 human } \\
\text { breast cancer cells }\end{array}$ & & \\
\hline
\end{tabular}


TABle 1: Continued.

\begin{tabular}{|c|c|c|c|c|c|}
\hline $\mathrm{ABC}$ transporter & PPAR & PPAR Ligand & Cell line & Transporter effect & Reference \\
\hline & & GW7845 & Primary human dendritic cells & $\uparrow \mathrm{BCRP}$ mRNA & {$[76]$} \\
\hline & & GW9662 & $\begin{array}{l}\text { Doxorubicin-resistant MCF7 human } \\
\text { breast cancer cells }\end{array}$ & $\downarrow$ BCRP protein & [69] \\
\hline
\end{tabular}

chemotherapy substrates as MDR1 [33]. Fasting-induced fatty acid release increased hepatic expression of Mdr2 mRNA and protein, as well as activity, in wild-type but not PPAR $\alpha$-knockout mice [77]. Similar results were observed in ciprofibrate-treated mice [73]. Interestingly, the latter trial demonstrated that elevated Mdr1 and Mdr3 mRNA expression accompanied Mdr2 induction in liver; however, in cultured mouse hepatocytes, only Mdr2 levels were elevated by $\operatorname{PPAR} \alpha$ agonists suggesting that in vivo induction of Mdr1 and Mdr3 may be influenced by PPAR $\alpha$ activation in surrounding tissue. Furthermore, both ciprofibrate and clofibrate increased hepatic expression of Mdr2 mRNA in $\mathrm{CF} 1$ mice. This was associated with increased Mdr2 redistribution into bile canaliculi and enhanced biliary phospholipid secretion [78]. Similarly, in a chimeric mouse model with humanized liver, bezafibrate increased hepatic MDR2/MDR3 mRNA and protein, and promoted canalicular localization of the transporter [71]. Bezafibrate-treated HepG2 human hepatocellular liver carcinoma cells also showed elevated expression of MDR2/MDR3 mRNA. Although there was no subsequent change in protein levels, there was a redistribution of the transporter into pseudocanaliculi between cells, accompanied by enhanced apical localization of phospholipids, which could be attenuated by PPAR $\alpha$ specific knockdown [72].

Several MRP1 homologs may also be upregulated by PPARs, including MRP2/ABCC2, MRP3/ABCC3, and MRP4/ABCC4, which are known to transport substrates belonging to a variety of chemotherapy drug classes [33]. Although their normal physiological function remains elusive, it has been suggested that these transporters may play a role in MDR $[79,80]$. Additionally, MRP4 expression may play a role in migration, as knockdown or pharmacological inhibition of this transporter appears to prevent human dendritic cell motility [81]. Moffit et al. examined the effect of clofibrate on hepatic transporters in mice. Following 10 days of dosing, clofibrate upregulated hepatic expression of Bcrp, Mrp3, and Mrp4 mRNA and protein in CD1 mice. Similar findings for Mrp3 and Mrp4 were detected in liver tissue isolated from clofibrate-treated wild-type SV129 mice, while no changes were seen in liver from similarly treated PPAR $\alpha$-knockout mice [82]. Liver expression of Mrp3 was also induced in C57BL mice treated with clofibrate, ciprofibrate, and diethylhexyl phthalate (DEHP) [83]. Maher et al. also reported the hepatic induction of Mrp3 and Mrp4 transcription in perfluorodecanoic-acid(PFDA-) treated mice [84]. This was associated with elevated serum levels of serum-conjugated bilirubin and bile acids indicative of Mrp3- and Mrp4-specific hepatic efflux activity. These effects were attenuated in $\operatorname{PPAR} \alpha$-knockout mice treated with PFDA. Several putative PPRE sequences were identified upstream of the Mrp3 and Mrp4 promoters, providing further evidence that PPAR $\alpha$ may directly regulate transcription of these transporters in the liver.

Activation of PPARs may also induce expression of BCRP. PPAR $\alpha$ agonists upregulate Bcrp transcription in mouse intestine [85]. Furthermore, PPAR $\alpha$-dependent activation induces BCRP expression and efflux activity in human cerebral endothelial cells [75]. Here, transporter induction is accompanied by binding of PPAR $\alpha$ to a PPRE within the BCRP promoter. In human monocyte-derived dendritic cells, BCRP was directly induced by ligand-activated PPAR $\gamma$ through three functional PPRE sequences located within the gene's promoter [76]. This enhancement of BCRP activity elevated drug efflux and maintained intracellular low levels of mitoxantrone, which could be reversed by addition of a BCRP inhibitor. In doxorubicin-resistant MCF7 breast cancer and K562 human leukemia cell lines, troglitazone downregulated expression of BCRP, and restored sensitivity to doxorubicin treatment [69]. Although troglitazone may elicit effects that are PPAR $\gamma$-dependent, it is also known to operate via pathways that are independent of this nuclear receptor [86]. Inhibition of PPAR $\gamma$ in untreated MCF7 cells reduced $\mathrm{BCRP}$ expression indicating that the observed effects of troglitazone were PPAR $\gamma$-independent, and providing evidence that this TZD may suppress BCRP transcription in these cells by indirectly antagonizing PPAR $\gamma$ itself.

In contrast to the studies previously outlined, a number of reports indicate that PPAR activation may inhibit ABC transporter expression and activity. Chen et al. observed that troglitazone increased PPAR $\gamma$ activity and reversed Pgpmediated chemoresistance in vincristine-resistant SGC7901 human gastric cancer cells [70]. Furthermore, Rajkumar and Yamuna performed genetic expression analysis on a doxorubicin-resistant 143B human osteosarcoma cell line and found increased expression of Pgp and Kruppel-like factor 2 [91]. Given that the latter is a known suppressor of PPAR $y$ expression [92], these findings may implicate the PPAR $y$ pathway as a negative regulator of Pgp transcription. Wang et al. also demonstrated that tumour necrosis factor (TNF) $\alpha$ could partially reverse MDR by inducing PPAR $\alpha$ and suppressing Pgp in an adriamycin-resistant cell line derived from HepG2 cells [93]. In another study, PPAR $\alpha$ agonists downregulated Mrp1 expression in mouse intestine [85]. Hepatic expression of Mrp2 protein was reduced in male Sprague-Dawley rats treated with the PPAR $\alpha$ agonists, clofibrate, DEHP, and PFDA [89]. Furthermore, efflux of bile acids by Mrp2 may be suppressed by troglitazone in cultured rat hepatocytes [74]. Both rosiglitazone and troglitazone inhibited BCRP function in BCRP-overexpressing MDCKII 
TABLE 2: In vivo effects of PPAR ligands on ABC transporters.

\begin{tabular}{|c|c|c|c|c|c|}
\hline $\mathrm{ABC}$ transporter & Ligand & Receptor & Model & Transporter effect & Reference \\
\hline \multirow[t]{5}{*}{$A B C A 1$} & $\operatorname{PPAR} \alpha$ & Fenofibrate & $\begin{array}{l}\text { Hypertriglyceridemic } \\
\text { patients }\end{array}$ & $\begin{array}{l}\text { Differential HDL synthesis due to } \\
\text { ABCA1 variants }\end{array}$ & {$[87]$} \\
\hline & & WY14643 & SV129 mice & $\begin{array}{l}\uparrow \text { Abcal mRNA and protein in } \\
\text { intestine }\end{array}$ & {$[88]$} \\
\hline & & & & $\downarrow$ intestinal absorption of cholesterol & \\
\hline & $\operatorname{PPAR} \gamma$ & Telmisartan & ApoE-/- C57BL mice & $\uparrow$ Abcal mRNA in aorta & {$[63]$} \\
\hline & & & & $\begin{array}{l}\downarrow \text { atherosclerotic lesion size and } \\
\text { number }\end{array}$ & \\
\hline Pgp/MDR1/ABCB1 & $\operatorname{PPAR} \alpha$ & Ciprofibrate & SV129 mice & $\uparrow$ hepatic Mdr1 \& Mdr3 mRNA & {$[73]$} \\
\hline \multirow[t]{14}{*}{$M D R 2 / M D R 3 / A B C B 4$} & $\operatorname{PPAR} \alpha$ & Bezafibrate & CF1 mice & $\uparrow$ hepatic Mdr2 mRNA & {$[78]$} \\
\hline & & & & $\uparrow$ bile secretion of phospholipid & \\
\hline & & & $\begin{array}{l}\text { Humanized liver-uPA/ } \\
\text { SCID chimeric mice }\end{array}$ & $\begin{array}{l}\uparrow \text { hepatic MDR2/MDR3 mRNA and } \\
\text { protein }\end{array}$ & {$[71]$} \\
\hline & & & & $\begin{array}{l}\uparrow \text { hepatic MDR2/MDR3 redistribution } \\
\text { into bile canaliculi }\end{array}$ & \\
\hline & & Ciprofibrate & SV129 mice & $\uparrow$ hepatic Mdr2 mRNA and protein & {$[73]$} \\
\hline & & & & $\begin{array}{l}\uparrow \text { bile secretion of cholesterol and } \\
\text { phospholipids }\end{array}$ & \\
\hline & & & CF1 mice & $\uparrow$ hepatic Mdr2 mRNA & {$[78]$} \\
\hline & & & & $\begin{array}{l}\uparrow \mathrm{Mdr} 2 \text { redistribution into bile } \\
\text { canaliculi }\end{array}$ & \\
\hline & & & & $\uparrow$ bile secretion of phospholipid & \\
\hline & & Clofibrate & CF1 mice & $\uparrow$ hepatic Mdr2 mRNA & {$[78]$} \\
\hline & & & & $\begin{array}{l}\uparrow \text { Mdr2 redistribution into bile } \\
\text { canaliculi }\end{array}$ & \\
\hline & & & & $\uparrow$ bile secretion of phospholipid & \\
\hline & & Fenofibrate & CF1 mice & $\uparrow$ hepatic Mdr2 mRNA & {$[78]$} \\
\hline & & Gemfibrozil & CF1 mice & $\uparrow$ hepatic Mdr2 mRNA & {$[78]$} \\
\hline \multirow[t]{4}{*}{$M R P 1 / A B C C 1$} & $\operatorname{PPAR} \alpha$ & Ciprofibrate & C57BL mice & $\downarrow$ hepatic Mrp1 mRNA & {$[83]$} \\
\hline & & Clofibrate & C57BL mice & $\downarrow$ hepatic Mrp1 mRNA & {$[83]$} \\
\hline & & GW7647 & C57BL mice & $\downarrow$ Mrp1 mRNA in small intestine & {$[85]$} \\
\hline & & WY14643 & C57BL mice & $\downarrow$ Mrp1 mRNA in small intestine & {$[85]$} \\
\hline \multirow[t]{3}{*}{$M R P 2 / A B C C 2$} & $\operatorname{PPAR} \alpha$ & Clofibrate & Sprague-Dawley rats & $\downarrow$ hepatic Mrp2 protein & {$[89]$} \\
\hline & & DEHP & Sprague-Dawley rats & $\downarrow$ hepatic Mrp2 protein & {$[89]$} \\
\hline & & PFDA & Sprague-Dawley rats & $\downarrow$ hepatic Mrp2 protein & {$[89]$} \\
\hline \multirow[t]{3}{*}{$M R P 3 / A B C C 3$} & $\operatorname{PPAR} \alpha$ & Ciprofibrate & C57BL mice & $\uparrow$ hepatic Mrp3 mRNA & {$[83]$} \\
\hline & & Clofibrate & C57BL mice & $\uparrow$ hepatic Mrp3 mRNA & {$[83]$} \\
\hline & & & $\begin{array}{l}\text { CD1 mice } \\
\text { SV129 mice }\end{array}$ & $\uparrow$ hepatic Mrp3 mRNA and protein & {$[82]$} \\
\hline
\end{tabular}


TABle 2: Continued.

\begin{tabular}{|c|c|c|c|c|c|}
\hline \multirow[t]{4}{*}{$\mathrm{ABC}$ transporter } & Ligand & Receptor & Model & Transporter effect & Reference \\
\hline & & DEHP & C57BL mice & $\uparrow$ hepatic Mrp3 mRNA & [83] \\
\hline & & PFDA & C57BL mice & $\uparrow$ hepatic Mrp3 mRNA & [84] \\
\hline & & & & $\begin{array}{l}\uparrow \text { serum levels of bilirubin and bile } \\
\text { acids }\end{array}$ & \\
\hline \multirow[t]{4}{*}{$M R P 4 / A B C C 4$} & $\operatorname{PPAR} \alpha$ & Clofibrate & CD1 mice & $\uparrow$ hepatic Mrp4 mRNA and protein & [82] \\
\hline & & & SV129 mice & & \\
\hline & & PFDA & C57BL mice & $\uparrow$ hepatic Mrp3 mRNA & {$[84]$} \\
\hline & & & & $\begin{array}{l}\uparrow \text { serum levels of bilirubin and bile } \\
\text { acids }\end{array}$ & \\
\hline \multirow[t]{4}{*}{$A B C G 1$} & PPAR $\alpha$ & Fenofibrate & Zucker diabetic fatty rats & $\uparrow \mathrm{Abcg} 1 \mathrm{mRNA}$ & [90] \\
\hline & & & & $\uparrow$ HDL particle size & \\
\hline & PPAR $\gamma$ & Telmisartan & ApoE-/- C57BL mice & $\uparrow$ Abcg1 mRNA in aorta & [63] \\
\hline & & & & $\begin{array}{l}\downarrow \text { atherosclerotic lesion size and } \\
\text { number }\end{array}$ & \\
\hline \multirow[t]{4}{*}{$B C R P / A B C G 2$} & $\operatorname{PPAR} \alpha$ & Clofibrate & CD1 mice & $\uparrow$ hepatic Bcrp mRNA and protein & {$[82]$} \\
\hline & & & SV129 mice & $\uparrow$ hepatic Bcrp mRNA & {$[82]$} \\
\hline & & GW7647 & C57BL mice & $\uparrow$ Bcrp mRNA in small intestine & [85] \\
\hline & & WY14643 & C57BL mice & $\uparrow$ Bcrp mRNA in small intestine & {$[85]$} \\
\hline
\end{tabular}

canine kidney epithelial cells, but induced its transcription in the HuH7 human hepatoma cell line [68]. These PPAR $\gamma$ activators also decreased Pgp-mediated drug efflux in doxorubicin-resistant P388 mouse leukemia cells. Moreover, fenofibrate suppressed Mdr1 transport activity in L-MDR1 porcine kidney epithelial cells [67]. Finally, in doxorubicinresistant MCF7 and K562 cells, troglitazone downregulated expression of Pgp and reversed chemoresistance to doxorubicin [69]. However, among these studies it was not clarified if these activities were dependent on PPAR activation and signaling.

From the laboratory perspective, the involvement of $\mathrm{ABC}$ transporters in MDR and other cancer hallmarks necessitate these genes as vital targets of chemotherapy, whereas their precise role in the clinical manifestation of cancer remains elusive. This is likely why clinical trials with Pgp inhibitors failed to reduce drug efflux and subsequent chemoresistance [94]. Regulation of ABC gene transcription by PPARs may be another option, but primarily, a detailed understanding of the functional and clinical relevance of the entire $\mathrm{ABC}$ transporter family in tumour samples and cell lines is obligatory. Future studies may identify new roles for $\mathrm{ABC}$ transporters in cancer, which could be targeted by either pharmacological inhibition or regulation of PPARs. Most of the evidence implies that PPARs are positive regulators of cancer-related $\mathrm{ABC}$ genes, indicating that transporter expression can be suppressed by antagonizing PPARs. On the other hand, controversial findings have also been reported; therefore, improved understanding of the mechanism by which PPARs regulate $\mathrm{ABC}$ genes is required. In particular, delineating the effects of PPAR-dependent and -independent signaling on $\mathrm{ABC}$ gene transcription will determine the precise link between PPARs and ABC transporters in cancer and may predict the success of PPAR ligand therapy in reversing MDR. Additional studies exploring the effect of PPAR activation as an adjuvant to chemotherapy in a wide range of drug-resistant cancer cell lines may also prove insightful.

\section{Atherosclerosis}

The atherosclerotic condition is characterized by the thickening of arterial vessels as a result of an accumulation of oxidized low-density lipoproteins (LDL), and subsequently, cholesterol-laden macrophages as a consequence of a maladaptive immune response. The associated chronic inflammation and necrosis drives plaque formation and vessel hardening, which can invariably lead to coronary artery disease (CAD) — the leading cause of death worldwide [95]. Interestingly, recent evidence suggests that PPAR induction of $\mathrm{ABC}$ transporter expression may improve lipid profiles through enhanced cholesterol cycling and excretion, and thus represents a promising avenue to prevent cardiovascular disease progression.

As noted above, PPAR $\alpha$ and PPAR $\gamma$ isoforms are also expressed in immune cells, such as mature macrophages, where they regulate genes involved in inflammation, differentiation, and TNF- $\alpha /$ IFN- $\gamma$-mediated apoptosis [96-98]. Expression of these two PPAR isoforms is also observed 
in macrophage foam cells that constitute atherosclerotic lesions [20, 99-101]. Recent studies suggest activating PPARs exerts antiatherosclerotic properties via improved cholesterol homeostasis through the regulation of specific $\mathrm{ABC}$ transporters. ABCA1 is one such transporter that controls apolipoprotein-A1- (apoA1-) mediated cholesterol efflux in macrophages [102]. Another, ABCG1, also promotes the transport of cholesterol from macrophages to HDL, although the underlying mechanism remains unclear [103]. This efflux is a critical step in reverse cholesterol transport, a process that allows for cholesterol displacement and excretion by the liver, and represents a protective modality against atherosclerotic risk.

Activation of PPAR $\gamma$ stimulates apoA1-mediated cholesterol efflux from human and mouse macrophages and foam cells through a signaling cascade that culminates in ABCA1 induction $[52,57,62]$. This activity is mediated via PPAR $\gamma$-dependent induction of liver $\mathrm{X}$ receptor ( $\operatorname{LXR} \alpha)$, an oxysterol-activated nuclear receptor, that triggers ABCA1 transcription via interaction with specific response elements in the ABCA1 promoter [104]. Although several putative PPRE sequences were initially identified in the LXR $\alpha$ promoter [105], only one was confirmed as a preferential PPAR $\gamma$ binding site in macrophages [57]. In addition, specific ligands for $\operatorname{PPAR} \alpha, \operatorname{PPAR} \beta / \delta$, and $\operatorname{PPAR} \gamma$ all increase $\operatorname{LXR} \alpha$ and ABCA1 mRNA and protein and enhance apoA1-mediated lipid efflux and HDL synthesis in THP1 macrophages, suggesting that non-PPRE-dependent regulatory mechanisms may be responsible for some of these activities [47, 51]. In a similar study, THP1 macrophages treated with various PPAR ligands revealed that PPAR $\beta / \delta$ activation induced greater ABCA1 mRNA expression and apoA1-mediated cholesterol efflux compared to PPAR $\alpha$ and PPAR $\gamma$ agonists [61]. Both rosiglitazone and pioglitazone treatment of THP1 macrophages also stimulated cholesterol efflux and induced ABCA1 mRNA and protein expression, implicating a regulatory role for PPAR $\gamma[56,58,59]$. Correspondingly, treatment of mouse RAW264.7 macrophagederived foam cells with conjugated linoleic acid (CLA) isomers ( $c 9 t 11$-CLA and $t 10 c 12$-CLA) or the hydroxylated derivative of linoleic acid (13-HODE), known ligands of both $\operatorname{PPAR} \alpha$ and PPAR $\gamma$, decreased cholesterol accumulation, enhanced cholesterol clearance, and induced expression of Abca1, and other genes involved in cholesterol homeostasis $[54,55]$. Similarly, in other tissues, such as canine gallbladder epithelial cells, and human mesangial and skeletal muscle cells, PPAR activators upregulate LXR $\alpha$-mediated ABCA1 transcription and prevent cholesterol accumulation [48, 53, 64].

Another PPAR $\gamma$ activator, telmisartan, induced Abca1 and Abcg1 expression in murine macrophages, and in the aorta of ApoE-deficient mice, where it suppressed macrophage proliferation and atherosclerotic progression [63]. It was also reported that the conditional deletion of PPAR $\gamma$ in macrophages led to decreased expression of LXR $\alpha$, Abcg1, and ApoE in mice [106]. This was accompanied by a significant reduction in cholesterol efflux from macrophages to HDL. Furthermore, granulocyte macrophage colony-stimulating factor (GM-CSF) knockout mice showed reduced expression of PPAR $\gamma$ and Abcg1 in alveolar macrophages of the lung. Given that GM-CSF is a known positive regulator of $\operatorname{PPAR} \gamma$, reintroduction of PPAR $\gamma$ in alveolar macrophages increased Abcg1 expression and cholesterol efflux activity and decreased intracellular lipid content [107]. Consequently, PPAR $\gamma$ activation by pioglitazone induced cholesterol efflux activity and increased ABCG1 mRNA and protein in THP1 and RAW264.7 macrophages [56]. Fenofibrate also stimulated Abcg1 transcription, which was associated with increased HDL particle size, in Zucker diabetic fatty rats [90].

In the liver, ABCA1 is implicated in control of HDL synthesis, which represents another means of protecting against atherosclerosis. HDLs are specialized carrier molecules in the blood that transport cholesterol from peripheral tissues and cholesterol-laden macrophages to the liver for excretion [108]. This process is thought to be the main mechanism underlying HDL's antiatherosclerotic properties [109]. Indeed, plasma HDL levels correspond inversely with cardiovascular risk [110]. Consequently, impaired ABCA1 activity is associated with low plasma HDL, which is linked to Tangier disease, familial HDL deficiency, and accelerated atherosclerosis [111]. Furthermore, Abcg1overexpressing transgenic mice have greater plasma HDL levels, improved cholesterol efflux from macrophages, and reduced atherosclerotic burden [112].

Several studies have demonstrated the ability of PPARs to regulate ABCA1 expression in the liver. In one study, PPAR activation with a variety of fibrates upregulated LXR $\alpha$ expression coupled with enhanced ABCA1 transcription and HDL biosynthesis in HepG2 cells [49]. Of the fibrates used, fenofibrate and LY518674 acted exclusively through $\operatorname{PPAR} \alpha$, while bezafibrate and gemfibrozil preferred PPAR $\gamma$ and $\operatorname{PPAR} \beta / \delta$, respectively, in addition to $\operatorname{PPAR} \alpha$ activity. Accordingly, antagonism of PPAR $\gamma$ in HepG2 cells blocked upregulation of ABCA1 mRNA and protein; however, PPAR $\gamma$ activation also reduced ABCA1 protein levels in this cell line despite increased ABCA1 transcription [60]. In this model, activation of PPAR $\gamma$ caused the dissociation of $\operatorname{LXR} \beta$ from ABCA1 at the cell membrane leading to increased ABCA1 protein degradation. Subsequently, translocation of $\operatorname{LXR} \beta$ to the nucleus increased ABCA1 transcription via binding of this nuclear receptor to the promoter region of the ABCA1 gene. Whether this affected HDL biosynthesis or cholesterol efflux from HepG2 cells remains to be seen.

Fasting-associated fatty acid release induces hepatic expression of Abca1, Abcg5, and Abcg8 in wild-type but not PPAR $\alpha$-null mice [77]. Although these ABC transporters are involved in hepatobiliary cholesterol transport, maximal cholesterol excretion from the liver was decreased by $\sim 50 \%$ after fasting. This raises the possibility of other PPARs and PPAR agonists playing a role in $\mathrm{ABC}$ transportermediated liver cholesterol efflux under normal conditions. More recently, a clinical trial examined the effect of fenofibrate treatment on HDL subclass particle concentrations on patients with triglycerides $\geq 150 \mathrm{mg} / \mathrm{dL}$ [87]. Following 3 weeks of therapy, stratification of participants by ABCA1 polymorphism genotypes revealed two variants (R1587K and $\mathrm{R} 219 \mathrm{~K}$ ) that were associated with significant increases 
in small HDL particles. This suggests a synergism between ABCA1 polymorphism and PPAR $\alpha$ agonists.

One of the most intuitive ways to reduce the burden of atherosclerosis is to regulate the uptake of dietary cholesterol at the intestine. In mice, intestinal expression of Abcal and Abcg8 is induced upon fasting [113]. Furthermore, normal mice maintained on a diet supplemented with a $\operatorname{PPAR} \alpha$ activator showed an increase in intestinal Abcal gene transcription and protein compared to PPAR $\alpha$-deficient mice, which showed no effect to treatment [88]. This increased expression was associated with a reduction in cholesterol absorption, as well as decreased plasma and liver cholesterol concentrations.

Atherosclerotic heart disease is undoubtedly one of the most devastating diseases worldwide. While pharmacological and dietary interventions that lower LDL levels remain the current treatment paradigm for atherosclerosis, they may only decrease the incidence of cardiovascular events by $\sim 30 \%$ [109]. The literature indicates that induction of $A B C A 1$ and $A B C G 1$ expression by PPAR activation may play a role in preventing atherosclerosis by improving cholesterol homeostasis and HDL synthesis. Moving forward, additional studies are required to address the clinical significance of these activities and to determine whether or not they are PPAR dependent. Clinical trials have begun to examine the effect of some PPAR activators in atherosclerosis, yielding a mixture of results. For example, fenofibrate treatment barely increased HDL levels and marginally lowered the incidence of CAD in high-risk patients with type 2 diabetes $[114,115]$. In a similar study, gemfibrozil significantly reduced CAD, in part, by elevating HDL [116]. Studies have also demonstrated that TZDs promote the destabilization of atherosclerotic plaques in nondiabetic patients [117], while still others report that these PPAR activators may actually increase the risk of heart failure in type 2 diabetics [118]. Despite these findings, a better understanding of the pleiotropic effects of PPARs and their role in atherosclerosis is required in order to design and develop appropriate PPAR-based therapies devoid of detrimental effects.

\section{Ichthyosis}

Derived from the Greek ichthys for "fish," ichthyosis refers to a group of dermatological disorders generally described by severely dry, cracked, and flaky skin that is thought to bear resemblance to fish scales [119]. The main pathophysiological feature of this disease is a failure of skin barrier permeability, leading to a spectrum of conditions ranging from the most mild, such as the common ichthyosis vulgaris, to the most severe, such as Harlequin type ichthyosis, which is rare but fatal in newborns. Recently, mutations in ABCA12, a keratinocyte lipid transporter, were shown to underlie the latter phenotype $[120,121]$. Under normal conditions, ABCA12 facilitates the uptake of lipids into specialized secretory granules, called lamellar bodies, within keratinocytes. These lipid-filled granules are then liberated from the cell where they release their cargo to the outermost layer of the epidermis, a requirement for normal formation of skin barrier permeability. On the other hand, ABCA12 deficiency prevents lipid loading into lamellar bodies, which leads to abnormal development of the skin and strikingly elevated rates of prenatal mortality [122].

While studies in this area are limited, they have demonstrated that ABCA12 may be regulated by PPARs, which may have important implications in Harlequin ichthyosis. Activation of PPARs promotes lamellar body secretion and improved epidermal barrier permeability in mice [123]. More recently, Jiang et al. demonstrated that ciglitazone, troglitazone, and the PPAR $\beta / \delta$ agonist, GW610742, induced expression of ABCA12 mRNA and protein in human keratinocytes [65]. Similarly, ceramide-induced transcription of ABCA12 was attenuated by siRNA knockdown of PPAR $\beta / \delta$, indicating that this activity was dependent on $\operatorname{PPAR} \beta / \delta[66]$. In a separate experiment, Jiang et al. also demonstrated that clofibrate and the PPAR $\beta / \delta$ ligand, GW501516, increased expression of the ABCA1 cholesterol efflux pump in human keratinocytes [50]. Given that these cells require cholesterol for adequate formation of permeability barrier function [124], ABCA1 regulation by PPARs may also play an important role in understanding the pathophysiology of Harlequin ichthyosis. These findings implicate the potential utility of PPAR ligands for the treatment of this disease, which should be further validated in vivo.

\section{Conclusion}

These studies describe compelling evidence for PPAR medicines in the regulation of $\mathrm{ABC}$ transporter expression and function. Beyond their respective individual roles in various human diseases, the overlap in tissue distribution and regulatory potential between PPARs and certain ABC transporters make this emerging story an attractive field for further research. They also provide an alternative approach when the targeting of $\mathrm{ABC}$ transporter genes in human cancer, atherosclerosis, or ichthyosis may suggest therapeutic advantages for patients. In addition, targeting $\mathrm{ABC}$ transporters at the transcriptional level may circumvent issues previously identified during focused inhibition of transporter activity. Furthermore, given the complex and multistage etiology of cancer and atherosclerosis, dual/pan PPAR modulators may prove especially useful in simultaneously regulating multiple PPAR isoforms and $\mathrm{ABC}$ transporters. For example, examining PPAR $\alpha / \gamma$ agonists like aleglitazar, currently being assessed for cardiovascular safety in Phase 3 clinical trials, for synergistic effects on multiple $\mathrm{ABC}$ transporters may prove a fruitful area for future studies. Improving our understanding of the interactions between PPARs, their ligands, and ABC transporters will further aid in developing more targeted therapeutic strategies to mitigate the burden of human disease on patients and the healthcare system.

\section{References}

[1] N. S. Wind and I. Holen, "Multidrug resistance in breast cancer: from in vitro models to clinical studies," International Journal of Breast Cancer, vol. 2011, Article ID 967419, 12 pages, 2011. 
[2] A. J. Slot, S. V. Molinski, and S. P. Cole, "Mammalian multidrug-resistance proteins (MRPs)," Essays in Biochemistry, vol. 50, no. 1, pp. 179-207, 2011.

[3] R. G. Deeley, C. Westlake, and S. P. C. Cole, “Transmembrane transport of endo- and xenobiotics by mammalian ATPbinding cassette multidrug resistance proteins," Physiological Reviews, vol. 86, no. 3, pp. 849-899, 2006.

[4] M. Dean, A. Rzhetsky, and R. Allikmets, "The human ATPbinding cassette $(\mathrm{ABC})$ transporter superfamily," Genome Research, vol. 11, no. 7, pp. 1156-1166, 2001.

[5] D. C. Rees, E. Johnson, and O. Lewinson, "ABC transporters: the power to change," Nature Reviews Molecular Cell Biology, vol. 10, no. 3, pp. 218-227, 2009.

[6] J. P. Berger, T. E. Akiyama, and P. T. Meinke, "PPARs: therapeutic targets for metabolic disease," Trends in Pharmacological Sciences, vol. 26, no. 5, pp. 244-251, 2005.

[7] R. Kostadinova, W. Wahli, and L. Michalik, "PPARs in diseases: control mechanisms of inflammation," Current Medicinal Chemistry, vol. 12, no. 25, pp. 2995-3009, 2005.

[8] J. M. Peters, Y. M. Shah, and F. J. Gonzalez, "The role of peroxisome proliferator-activated receptors in carcinogenesis and chemoprevention," Nature Reviews Cancer, vol. 12, pp. 181-195, 2012.

[9] A. Montagner, G. Rando, G. Degueurce, N. Leuenberger, L. Michalik, and W. Wahli, "New insights into the role of PPARs," Prostaglandins Leukotrienes and Essential Fatty Acids, vol. 85, no. 5, pp. 235-243, 2011.

[10] Y. X. Wang, "PPARs: diverse regulators in energy metabolism and metabolic diseases," Cell Research, vol. 20, no. 2, pp. 124 $137,2010$.

[11] L. Michalik, J. Auwerx, J. P. Berger et al., "International union of pharmacology. LXI. Peroxisome proliferator-activated receptors," Pharmacological Reviews, vol. 58, no. 4, pp. 726$741,2006$.

[12] T. M. Willson, P. J. Brown, D. D. Sternbach, and B. R. Henke, "The PPARs: from orphan receptors to drug discovery," Journal of Medicinal Chemistry, vol. 43, no. 4, pp. 527-550, 2000.

[13] A. I. Shulman and D. J. Mangelsdorf, "Retinoid X receptor heterodimers in the metabolic syndrome," New England Journal of Medicine, vol. 353, no. 6, pp. 604-615, 2005.

[14] M. Ricote and C. K. Glass, "PPARs and molecular mechanisms of transrepression," Biochimica et Biophysica Acta, vol. 1771, no. 8, pp. 926-935, 2007.

[15] D. Auboeuf, J. Rieusset, L. Fajas et al., "Tissue distribution and quantification of the expression of mRNAs of peroxisome proliferator-activated receptors and liver $\mathrm{X}$ receptor$\alpha$ in humans: no alteration in adipose tissue of obese and NIDDM patients," Diabetes, vol. 46, no. 8, pp. 1319-1327, 1997.

[16] I. Issemann and S. Green, "Activation of a member of the steroid hormone receptor superfamily by peroxisome proliferators," Nature, vol. 347, no. 6294, pp. 645-650, 1990.

[17] C. Pirat, A. Farce, N. Lebegue et al., "Targeting peroxisome proliferator-activated receptors (PPARs): development of modulators," Journal of Medicinal Chemistry, vol. 55, no. 94, pp. 4027-4061, 2012.

[18] A. Chawla, E. J. Schwarz, D. D. Dimaculangan, and M. A. Lazar, "Peroxisome proliferator-activated receptor (PPAR) $\gamma$ : adipose-predominant expression and induction early in adipocyte differentiation," Endocrinology, vol. 135, no. 2, pp. 798-800, 1994.
[19] J. Plutzky, "Inflammation in atherosclerosis and diabetes mellitus," Reviews in Endocrine and Metabolic Disorders, vol. 5, no. 3, pp. 255-259, 2004.

[20] M. Ricote, J. Huang, L. Fajas et al., "Expression of the peroxisome proliferator-activated receptor $\gamma(\operatorname{PPAR} \gamma)$ in human atherosclerosis and regulation in macrophages by colony stimulating factors and oxidized low density lipoprotein," Proceedings of the National Academy of Sciences of the United States of America, vol. 95, no. 13, pp. 7614-7619, 1998.

[21] B. M. Spiegelman, "PPAR- $\gamma$ : adipogenic regulator and thiazolidinedione receptor," Diabetes, vol. 47, no. 4, pp. 507-514, 1998.

[22] G. Daniel, "Risk of cardiovascular events and all-cause mortality among commercially-insured patients treated with thiazolidinediones," in Proceedings of the FDA Joint Meeting of the Endocrinologic and Metabolic Drugs Advisory Committee and the Drug Safety and Risk Management Advisory Committee, July 2010.

[23] C. Piccinni, D. Motola, G. Marchesini, and E. Poluzzi, "Assessing the association of pioglitazone use and bladder cancer through drug adverse event reporting," Diabetes Care, vol. 34, no. 6, pp. 1369-1371, 2011.

[24] J. Woodcock, J. M. Sharfstein, and M. Hamburg, "Regulatory action on rosiglitazone by the U.S. Food and Drug Administration," New England Journal of Medicine, vol. 363, no. 16, pp. 1489-1491, 2010.

[25] "FDA Drug Safety Communication: Updated drug labels for pioglitazone-containing medicines," http://www.fda.gov/ Drugs/DrugSafety/ucm266555.htm.

[26] "Avandia (rosiglitazone): REMS—Risk of Cardiovascular Events," http://www.fda.gov/Safety/MedWatch/SafetyInformation/SafetyAlertsforHumanMedicalProducts/ucm 226994 .htm?utm_source=fdaSearch\&utm_medium=website\&utm term=rosiglitazone\&utm_content $=1 \% 7 \mathrm{D}$.

[27] E. Adeghate, A. Adem, M.Y. Hasan, K. Tekes, and H. Kalasz, "Medicinal chemistry and actions of dual and pan PPAR modulators," The Open Medicinal Chemistry Journal, vol. 5, supplement 2, pp. 93-98, 2011.

[28] M. M. Gottesman, T. Fojo, and S. E. Bates, "Multidrug resistance in cancer: role of ATP-dependent transporters," Nature Reviews Cancer, vol. 2, no. 1, pp. 48-58, 2002.

[29] R. L. Juliano and V. Ling, "A surface glycoprotein modulating drug permeability in Chinese hamster ovary cell mutants," Biochimica et Biophysica Acta, vol. 455, no. 1, pp. 152-162, 1976.

[30] S. V. Ambudkar, C. Kimchi-Sarfaty, Z. E. Sauna, and M. M. Gottesman, "P-glycoprotein: from genomics to mechanism," Oncogene, vol. 22, no. 47, pp. 7468-7485, 2003.

[31] E. Mechetner, A. Kyshtoobayeva, S. Zonis et al., "Levels of multidrug resistance (MDR1) P-glycoprotein expression by human breast cancer correlate with in vitro resistance to taxol and doxorubicin," Clinical Cancer Research, vol. 4, no. 2, pp. 389-398, 1998.

[32] C. Atalay, I. D. Gurhan, C. Irkkan, and U. Gunduz, "Multidrug resistance in locally advanced breast cancer," Tumor Biology, vol. 27, no. 6, pp. 309-318, 2006.

[33] J. I. Fletcher, M. Haber, M. J. Henderson, and M. D. Norris, "ABC transporters in cancer: more than just drug efflux pumps," Nature Reviews Cancer, vol. 10, no. 2, pp. 147-156, 2010.

[34] S. P. C. Cole, G. Bhardwaj, J. H. Gerlach et al., "Overexpression of a transporter gene in a multidrug-resistant human lung cancer cell line," Science, vol. 258, no. 5088, pp. 1650$1654,1992$. 
[35] G. Szakács, J. K. Paterson, J. A. Ludwig, C. Booth-Genthe, and M. M. Gottesman, "Targeting multidrug resistance in cancer," Nature Reviews Drug Discovery, vol. 5, no. 3, pp. 219234, 2006.

[36] M. Munoz, M. Henderson, M. Haber, and M. Norris, "Role of the MRP1/ABCC1 multidrug transporter protein in cancer," IUBMB Life, vol. 59, no. 12, pp. 752-757, 2007.

[37] M. Maliepaard, G. L. Scheffer, I. F. Faneyte et al., "Subcellular localization and distribution of the Breast Resistance Protein Transporter in normal human tissues," Cancer Research, vol. 61, no. 8, pp. 3458-3464, 2001.

[38] S. Zhou, J. D. Schuetz, K. D. Bunting et al., "The ABC transporter Bcrp1/ABCG2 is expressed in a wide variety of stem cells and is a molecular determinant of the sidepopulation phenotype," Nature Medicine, vol. 7, no. 9, pp. 1028-1034, 2001.

[39] K. Miyake, L. Mickley, T. Litman et al., "Molecular cloning of cDNAs which are highly overexpressed in mitoxantroneresistant cells: demonstration of homology to $\mathrm{ABC}$ transport genes," Cancer Research, vol. 59, no. 1, pp. 8-13, 1999.

[40] J. W. Jonker, J. W. Smit, R. F. Brinkhuis et al., "Role of breast cancer resistance protein in the bioavailability and fetal penetration of topotecan," Journal of the National Cancer Institute, vol. 92, no. 20, pp. 1651-1656, 2000.

[41] S. Kawabata, M. Oka, K. Shiozawa et al., "Breast cancer resistance protein directly confers $\mathrm{SN}-38$ resistance of lung cancer cells," Biochemical and Biophysical Research Communications, vol. 280, no. 5, pp. 1216-1223, 2001.

[42] L. J. Robinson, W. K. Roberts, T. T. Ling, D. Lamming, S. S. Sternberg, and P. D. Roepe, "Human MDR 1 protein overexpression delays the apoptotic cascade in Chinese hamster ovary fibroblasts," Biochemistry, vol. 36, no. 37, pp. 11169-11178, 1997.

[43] M. J. Smyth, E. Krasovskis, V. R. Sutton, and R. W. Johnstone, "The drug efflux protein, P-glycoprotein, additionally protects drug-resistant tumor cells from multiple forms of caspase-dependent apoptosis," Proceedings of the National Academy of Sciences of the United States of America, vol. 95, no. 12, pp. 7024-7029, 1998.

[44] K. M. Tainton, M. J. Smyth, J. T. Jackson et al., "Mutational analysis of P-glycoprotein: suppression of caspase activation in the absence of ATP-dependent drug efflux," Cell Death and Differentiation, vol. 11, no. 9, pp. 1028-1037, 2004.

[45] K. E. Miletti-González, S. Chen, N. Muthukumaran et al., "The CD44 receptor interacts with P-glycoprotein to promote cell migration and invasion in cancer," Cancer Research, vol. 65, no. 15, pp. 6660-6667, 2005.

[46] S. B. Kaye, "Reversal of drug resistance in ovarian cancer: where do we go from here?" Journal of Clinical Oncology, vol. 26, no. 16, pp. 2616-2618, 2008.

[47] M. Ogata, M. Tsujita, M. A. Hossain et al., "On the mechanism for PPAR agonists to enhance ABCA1 gene expression," Atherosclerosis, vol. 205, no. 2, pp. 413-419, 2009.

[48] X. Z. Ruan, J. F. Moorhead, R. Fernando, D. C. Wheeler, S. H. Powis, and Z. Varghese, "PPAR agonists protect mesangial cells from interleukin $1 \beta$-induced intracellular lipid accumulation by activating the ABCA1 cholesterol efflux pathway," Journal of the American Society of Nephrology, vol. 14, no. 3, pp. 593-600, 2003.

[49] M. A. Hossain, M. Tsujita, F. J. Gonzalez, and S. Yokoyama, "Effects of fibrate drugs on expression of ABCA1 and HDL biogenesis in hepatocytes," Journal of Cardiovascular Pharmacology, vol. 51, no. 3, pp. 258-266, 2008.
[50] Y. J. Jiang, B. Lu, P. Kim, P. M. Elias, and K. R. Feingold, "Regulation of ABCA1 expression in human keratinocytes and murine epidermis," Journal of Lipid Research, vol. 47, no. 10, pp. 2248-2258, 2006.

[51] R. Arakawa, N. Tamehiro, T. Nishimaki-Mogami, K. Ueda, and S. Yokoyama, "Fenofibric acid, an active form of fenofibrate, increases apolipoprotein A-I-mediated highdensity lipoprotein biogenesis by enhancing transcription of ATP-binding cassette transporter A1 gene in a liver $\mathrm{X}$ receptor-dependent manner," Arteriosclerosis, Thrombosis, and Vascular Biology, vol. 25, no. 6, pp. 1193-1197, 2005.

[52] G. Chinetti, S. Lestavel, V. Bocher et al., "PPAR- $\alpha$ and PPAR- $\gamma$ activators induce cholesterol removal from human macrophage foam cells through stimulation of the ABCA1 pathway," Nature Medicine, vol. 7, no. 1, pp. 53-58, 2001.

[53] J. Lee, E. M. Hong, H. W. Byun et al., "The effect of PPAR $\alpha$ and PPAR $\gamma$ ligands on inflammation and ABCA1 expression in cultured gallbladder epithelial cells," Digestive Diseases and Sciences, vol. 53, no. 6, pp. 1707-1715, 2008.

[54] I. Kammerer, R. Ringseis, R. Biemann, G. Wen, and K. Eder, "13-hydroxy linoleic acid increases expression of the cholesterol transporters ABCA1, ABCG1 and SR-BI and stimulates apoA-I-dependent cholesterol efflux in RAW264.7 macrophages," Lipids in Health and Disease, vol. 10, article 222, 2011.

[55] R. Ringseis, G. Wen, D. Saal, and K. Eder, "Conjugated linoleic acid isomers reduce cholesterol accumulation in acetylated LDL-induced mouse RAW264.7 macrophagederived foam cells," Lipids, vol. 43, no. 10, pp. 913-923, 2008.

[56] H. Ozasa, M. Ayaori, M. Iizuka et al. et al., "Pioglitazone enhances cholesterol efflux from macrophages by increasing ABCA1/ABCG1 expressions via PPARgamma/LXRalpha pathway: findings from in vitro and ex vivo studies," Atherosclerosis, vol. 219, no. 1, pp. 141-150, 2011.

[57] A. Chawla, W. A. Boisvert, C. H. Lee et al., "A PPAR $\gamma$-LXRABCA1 pathway in macrophages is involved in cholesterol efflux and atherogenesis," Molecular Cell, vol. 7, no. 1, pp. 161-171, 2001.

[58] G. Llaverias, D. Lacasa, M. Viñals et al., "Reduction of intracellular cholesterol accumulation in THP-1 macrophages by a combination of rosiglitazone and atorvastatin," Biochemical Pharmacology, vol. 68, no. 1, pp. 155-163, 2004.

[59] G. Llaverias, A. Rebollo, J. Pou et al., "Effects of rosiglitazone and atorvastatin on the expression of genes that control cholesterol homeostasis in differentiating monocytes," Biochemical Pharmacology, vol. 71, no. 5, pp. 605-614, 2006.

[60] D. A. Mogilenko, V. S. Shavva, E. B. Dizhe, S. V. Orlov, and A. P. Perevozchikov, "PPAR $\gamma$ activates ABCA1 gene transcription but reduces the level of ABCA1 protein in HepG2 cells," Biochemical and Biophysical Research Communications, vol. 402, no. 3, pp. 477-482, 2010.

[61] W. R. Oliver, J. L. Shenk, M. R. Snaith et al., "A selective peroxisome proliferator-activated receptor $\delta$ agonist promotes reverse cholesterol transport," Proceedings of the National Academy of Sciences of the United States of America, vol. 98, no. 9, pp. 5306-5311, 2001.

[62] Y. Xu, F. Lai, Y. Wu et al., "Mycophenolic acid induces ATPbinding cassette transporter A1 (ABCA1) expression through the PPARgamma-LXRalpha-ABCA1 pathway," Biochemical and Biophysical Research Communications, vol. 414, no. 4, pp. 779-782, 2011.

[63] T. Matsumura, H. Kinoshita, N. Ishii et al., "Telmisartan exerts antiatherosclerotic effects by activating peroxisome proliferator-activated receptor- $\gamma$ in macrophages," 
Arteriosclerosis, Thrombosis, and Vascular Biology, vol. 31, no. 6, pp. 1268-1275, 2011.

[64] D. L. Sprecher, C. Massien, G. Pearce et al., "Triglyceride: high-density lipoprotein cholesterol effects in healthy subjects administered a peroxisome proliferator activated receptor $\delta$ agonist," Arteriosclerosis, Thrombosis, and Vascular Biology, vol. 27, no. 2, pp. 359-365, 2007.

[65] Y. J. Jiang, B. Lu, P. Kim et al., "PPAR and LXR activators regulate ABCA12 expression in human keratinocytes," Journal of Investigative Dermatology, vol. 128, no. 1, pp. 104-109, 2008.

[66] Y. J. Jiang, Y. Uchida, B. Lu et al., "Ceramide stimulates ABCA12 expression via peroxisome proliferator-activated receptor $\delta$ in human keratinocytes," Journal of Biological Chemistry, vol. 284, no. 28, pp. 18942-18952, 2009.

[67] M. Ehrhardt, H. Lindenmaier, J. Burhenne, W. E. Haefeli, and J. Weiss, "Influence of lipid lowering fibrates on Pglycoprotein activity in vitro," Biochemical Pharmacology, vol. 67, no. 2, pp. 285-292, 2004.

[68] J. Weiss, A. Sauer, M. Herzog, R. H. Böger, W. E. Haefeli, and R. A. Benndorf, "Interaction of thiazolidinediones (glitazones) with the ATP-Binding cassette transporters Pglycoprotein and breast cancer resistance protein," Pharmacology, vol. 84, no. 5, pp. 264-270, 2009.

[69] G. F. Davies, B. H. J. Juurlink, and T. A. A. Harkness, “Troglitazone reverses the multiple drug resistance phenotype in cancer cells," Drug Design, Development and Therapy, no. 3, pp. 79-88, 2009.

[70] Q. Chen, J. Zhou, C. Jiang, and J. Chen, "Reversal of P-glycoprotein-mediated multidrug resistance in SGC7901/VCR cells by PPAR $\gamma$ activation by troglitazone," Journal of Huazhong University of Science and Technology, Medical Science, vol. 30, no. 3, pp. 326-331, 2010.

[71] J. Shoda, K. Okada, Y. Inada et al., "Bezafibrate induces multidrug-resistance P-Glycoprotein 3 expression in cultured human hepatocytes and humanized livers of chimeric mice," Hepatology Research, vol. 37, no. 7, pp. 548-556, 2007.

[72] J. Shoda, Y. Inada, A. Tsuji et al., "Bezafibrate stimulates canalicular localization of NBD-labeled PC in HepG2 cells by PPAR $\alpha$-mediated redistribution of ABCB4," Journal of Lipid Research, vol. 45, no. 10, pp. 1813-1825, 2004.

[73] T. Kok, V. W. Bloks, H. Wolters et al., "Peroxisome proliferator-activated receptor $\alpha(\operatorname{PPAR} \alpha)$-mediated regulation of multidrug resistance 2 (Mdr2) expression and function in mice," Biochemical Journal, vol. 369, no. 3, pp. 539-547, 2003.

[74] T. L. Marion, C. H. Perry, I. R. L. S. Claire, W. Yue, and K. L. R. Brouwer, "Differential disposition of chenodeoxycholic acid versus taurocholic acid in response to acute troglitazone exposure in rat hepatocytes," Toxicological Sciences, vol. 120, no. 2, Article ID kfr014, pp. 371-380, 2011.

[75] M. T. Hoque, K. R. Robillard, and R. Bendayan, "Regulation of breast cancer resistant protein (BCRP) by peroxisome proliferator-activated receptor Alpha (PPARalpha) in human brain microvessel endothelial cells," Molecular Pharmacology, vol. 81, no. 4, pp. 598-609, 2012.

[76] I. Szatmari, G. Vámosi, P. Brazda et al., "Peroxisome proliferator-activated receptor $\gamma$-regulated ABCG2 expression confers cytoprotection to human dendritic cells," Journal of Biological Chemistry, vol. 281, no. 33, pp. 23812-23823, 2006.

[77] T. Kok, H. Wolters, V. W. Bloks et al., "Induction of hepatic $\mathrm{ABC}$ transporter expression is part of the PPAr $\alpha$-mediated fasting response in the mouse," Gastroenterology, vol. 124, no. 1, pp. 160-171, 2003.
[78] J. Chianale, V. Vollrath, A. M. Wielandt et al., "Fibrates induce mdr2 gene expression and biliary phospholipid secretion in the mouse," Biochemical Journal, vol. 314, no. 3, pp. 781-786, 1996.

[79] K. Yoh, G. Ishii, T. Yokose et al., "Breast cancer resistance protein impacts clinical outcome in platinum-based chemotherapy for advanced non-small cell lung cancer," Clinical Cancer Research, vol. 10, no. 5, pp. 1691-1697, 2004.

[80] M. Kool, M. De Haas, G. L. Scheffer et al., "Analysis of expression of cMOAT (MRP2), MRP3, MRP4, and MRP5, homologues of the multidrug resistance-associated protein gene (MRP1), in human cancer cell lines," Cancer Research, vol. 57, no. 16, pp. 3537-3547, 1997.

[81] R. Van De Ven, G. L. Seheffer, A. W. Reurs et al., "A role for multidrug resistance protein 4 (MRP4; ABCC4) in human dendritic cell migration," Blood, vol. 112, no. 6, pp. 23532359, 2008.

[82] J. S. Moffit, L. M. Aleksunes, J. M. Maher, G. L. Scheffer, C. D. Klaassen, and J. E. Manautou, "Induction of hepatic transporters multidrug resistance-associated proteins (Mrp) 3 and 4 by clofibrate is regulated by peroxisome proliferatoractivated receptor $\alpha$," Journal of Pharmacology and Experimental Therapeutics, vol. 317, no. 2, pp. 537-545, 2006.

[83] J. M. Maher, X. Cheng, A. L. Slitt, M. Z. Dieter, and C. D. Klaassen, "Induction of the multidrug resistanceassociated protein family of transporters by chemical activators of receptor-mediated pathways in mouse liver," Drug Metabolism and Disposition, vol. 33, no. 7, pp. 956-962, 2005.

[84] J. M. Maher, L. M. Aleksunes, M. Z. Dieter et al., "Nrf2and PPAR $\alpha$-mediated regulation of hepatic mrp transporters after exposure to perfluorooctanoic acid and perfluorodecanoic acid," Toxicological Sciences, vol. 106, no. 2, pp. 319328, 2008.

[85] T. Hirai, Y. Fukui, and K. Motojima, "PPAR $\alpha$ agonists positively and negatively regulate the expression of several nutrient/drug transporters in mouse small intestine," Biological and Pharmaceutical Bulletin, vol. 30, no. 11, pp. 21852190, 2007.

[86] S. Salomone, "Pleiotropic effects of glitazones: a double edge sword?" Front Pharmacol, vol. 2, article 14, 2011.

[87] M. Y. Tsai, J. M. Ordovas, N. Li et al., "Effect of fenofibrate therapy and ABCA1 polymorphisms on highdensity lipoprotein subclasses in the Genetics of Lipid Lowering Drugs and Diet Network," Molecular Genetics and Metabolism, vol. 100, no. 2, pp. 118-122, 2010.

[88] B. L. Knight, D. D. Patel, S. M. Humphreys, D. Wiggins, and G. F. Gibbons, "Inhibition of cholesterol absorption associated with a PPAR $\alpha$-dependent increase in ABC binding cassette transporter A1 in mice," Journal of Lipid Research, vol. 44, no. 11, pp. 2049-2058, 2003.

[89] D. R. Johnson and C. D. Klaassen, "Regulation of rat multidrug resistance protein 2 by classes of prototypical microsomal enzyme inducers that activate distinct transcription pathways," Toxicological Sciences, vol. 67, no. 2, pp. 182189, 2002.

[90] J. Tanabe, N. Tamasawa, M. Yamashita et al., "Effects of combined PPAR $\gamma$ and $\operatorname{PPAR} \alpha$ agonist therapy on reverse cholesterol transport in the Zucker diabetic fatty rat," Diabetes, Obesity and Metabolism, vol. 10, no. 9, pp. 772-779, 2008.

[91] T. Rajkumar and M. Yamuna, "Multiple pathways are involved in drug resistance to doxorubicin in an osteosarcoma cell line," Anti-Cancer Drugs, vol. 19, no. 3, pp. 257265, 2008. 
[92] S. L. Schober, K. Chay T, K. S. Schluns, L. Lefrancois, J. M. Leiden, and S. C. Jameson, "Expression of the transcription factor lung Kruppel-like factor is regulated by cytokines and correlates with survival memory T cells in vitro and in vivo," Journal of Immunology, vol. 163, no. 7, pp. 3662-3667, 1999.

[93] Q. Wang, X. P. Chen, S. Hai et al., "TNF-alpha induced reversal of multidrug resistance in human hepatocellular carcinoma cells," Zhonghua Wai Ke Za Zhi, vol. 45, no. 9, pp. 602-604, 2007.

[94] L. D. Cripe, H. Uno, E. M. Paietta et al., "Zosuquidar, a novel modulator of P-glycoprotein, does not improve the outcome of older patients with newly diagnosed acute myeloid leukemia: a randomized, placebo-controlled trial of the Eastern Cooperative Oncology Group 3999," Blood, vol. 116, no. 20, pp. 4077-4085, 2010.

[95] C. Weber and H. Noels, "Atherosclerosis: current pathogenesis and therapeutic options," Nature Medicine, vol. 17, no. 11, pp. 1410-1422, 2011.

[96] C. Jiang, A. T. Ting, and B. Seed, "PPAR- $\gamma$ agonists inhibit production of monocyte inflammatory cytokines," Nature, vol. 391, no. 6662, pp. 82-86, 1998.

[97] M. Ricote, A. C. Li, T. M. Willson, C. J. Kelly, and C. K. Glass, "The peroxisome proliferator-activated receptor- $\gamma$ is a negative regulator of macrophage activation," Nature, vol. 391, no. 6662, pp. 79-82, 1998.

[98] G. Chinetti, S. Griglio, M. Antonucci et al., "Activation of proliferator-activated receptors $\alpha$ and $\gamma$ induces apoptosis of human monocyte-derived macrophages," Journal of Biological Chemistry, vol. 273, no. 40, pp. 25573-25580, 1998.

[99] P. Tontonoz, L. Nagy, J. G. A. Alvarez, V. A. Thomazy, and R. M. Evans, "PPAR $\gamma$ promotes monocyte/macrophage differentiation and uptake of oxidized LDL," Cell, vol. 93, no. 2, pp. 241-252, 1998.

[100] N. Marx, G. Sukhova, C. Murphy, P. Libby, and J. Plutzky, "Macrophages in human atheroma contain PPAR $\gamma$ : differentiation-dependent peroxisomal proliferator-activated receptor $\gamma$ (PPAR $\gamma)$ expression and reduction of MMP-9 activity through PPAR $y$ activation in mononuclear phagocytes in vitro," American Journal of Pathology, vol. 153, no. 1, pp. 17-23, 1998.

[101] G. Chinetti, F. G. Gbaguidi, S. Griglio et al., "CLA-1/SR$\mathrm{BI}$ is expressed in atherosclerotic lesion macrophages and regulated by activators of peroxisome proliferator-activated receptors," Circulation, vol. 101, no. 20, pp. 2411-2417, 2000.

[102] R. M. Lawn, D. P. Wade, M. R. Garvin et al., "The Tangier disease gene product $\mathrm{ABC} 1$ controls the cellular apolipoprotein-mediated lipid removal pathway," Journal of Clinical Investigation, vol. 104, no. 8, pp. R25-R31, 1999.

[103] N. Wang, D. Lan, W. Chen, F. Matsuura, and A. R. Tall, "ATPbinding cassette transporters G1 and G4 mediate cellular cholesterol efflux to high-density lipoproteins," Proceedings of the National Academy of Sciences of the United States of America, vol. 101, no. 26, pp. 9774-9779, 2004.

[104] P. Costet, Y. Luo, N. Wang, and A. R. Tall, "Sterol-dependent transactivation of the $\mathrm{ABC} 1$ promoter by the liver $\mathrm{X}$ receptor/retinoid X receptor," Journal of Biological Chemistry, vol. 275, no. 36, pp. 28240-28245, 2000.

[105] K. A. R. Tobin, H. H. Steineger, S. Albert et al., "Cross-talk between fatty acid and cholesterol metabolism mediated by liver X receptor- $\alpha$," Molecular Endocrinology, vol. 14, no. 5, pp. 741-752, 2000.

[106] T. E. Akiyama, S. Sakai, G. Lambert et al., "Conditional disruption of the peroxisome proliferator-activated receptor $\gamma$ gene in mice results in lowered expression of ABCA1,
ABCG1, and apoE in macrophages and reduced cholesterol efflux," Molecular and Cellular Biology, vol. 22, no. 8, pp. 2607-2619, 2002.

[107] A. Malur, A. D. Baker, A. J. McCoy et al., "Restoration of PPAR $\gamma$ reverses lipid accumulation in alveolar macrophages of GM-CSF knockout mice," American Journal of Physiology, vol. 300, no. 1, pp. L73-L80, 2011.

[108] C. J. Fielding and P. E. Fielding, "Molecular physiology of reverse cholesterol transport," Journal of Lipid Research, vol. 36, no. 2, pp. 211-228, 1995.

[109] A. R. Tall, "Cholesterol efflux pathways and other potential mechanisms involved in the athero-protective effect of high density lipoproteins," Journal of Internal Medicine, vol. 263, no. 3, pp. 256-273, 2008.

[110] H. B. Brewer, "High-density lipoproteins: a new potential therapeutic target for the prevention of cardiovascular disease," Arteriosclerosis, Thrombosis, and Vascular Biology, vol. 24, no. 3, pp. 387-391, 2004.

[111] S. Rust, M. Rosier, H. Funke et al., "Tangier disease is caused by mutations in the gene encoding ATP-binding cassette transporter 1," Nature Genetics, vol. 22, no. 4, pp. 352-355, 1999.

[112] M. J. Price and P. K. Shah, "New strategies in managing and preventing atherosclerosis: focus on HDL," Reviews in Cardiovascular Medicine, vol. 3, no. 3, pp. 129-137, 2002.

[113] H. M. van den Bosch, M. Bünger, P. J. de Groot, J. van der Meijde, G. J. E. J. Hooiveld, and M. Müller, "Gene expression of transporters and phase I/II metabolic enzymes in murine small intestine during fasting," BMC Genomics, vol. 8, article 267, 2007.

[114] P. J. Barter and K. A. Rye, "Is there a role for fibrates in the management of dyslipidemia in the metabolic syndrome?" Arteriosclerosis, Thrombosis, and Vascular Biology, vol. 28, no. 1, pp. 39-46, 2008.

[115] A. Keech, R. J. Simes, P. Barter et al., "Effects of long-term fenofibrate therapy on cardiovascular events in 9795 people with type 2 diabetes mellitus (the FIELD study): randomised controlled trial," The Lancet, vol. 366, no. 9500, pp. 18491861, 2005.

[116] S. J. Robins, D. Collins, J. T. Wittes et al., "Relation of gemfibrozil treatment and lipid levels with major coronary events. VA-HIT: a randomized controlled trial," Journal of the American Medical Association, vol. 285, no. 12, pp. 15851591, 2001.

[117] K. A. M. Jandeleit-Dahm, A. Calkin, C. Tikellis, and M. Thomas, "Direct antiatherosclerotic effects of PPAR agonists," Current Opinion in Lipidology, vol. 20, no. 1, pp. 24-29, 2009.

[118] P. D. Home, S. J. Pocock, H. Beck-Nielsen et al., "Rosiglitazone evaluated for cardiovascular outcomes in oral agent combination therapy for type 2 diabetes (RECORD): a multicentre, randomised, open-label trial," The Lancet, vol. 373, no. 9681, pp. 2125-2135, 2009.

[119] M. Schmuth, R. Gruber, P. M. Elias, and M. L. Williams, "Ichthyosis update: towards a function-driven model of pathogenesis of the disorders of cornification and the role of corneocyte proteins in these disorders," Advances in Dermatology, vol. 23, pp. 231-256, 2007.

[120] M. Akiyama, Y. Sugiyama-Nakagiri, K. Sakai et al., "Mutations in lipid transporter ABCA12 in harlequin ichthyosis and functional recovery by corrective gene transfer," Journal of Clinical Investigation, vol. 115, no. 7, pp. 1777-1784, 2005.

[121] D. P. Kelsell, E. E. Norgett, H. Unsworth et al., "Mutations in ABCA12 underlie the severe congenital skin disease 
harlequin ichthyosis," American Journal of Human Genetics, vol. 76, no. 5, pp. 794-803, 2005.

[122] M. Akiyama, "Pathomechanisms of harlequin ichthyosis and ABCA transporters in human diseases," Archives of Dermatology, vol. 142, no. 7, pp. 914-918, 2006.

[123] M. Q. Man, E. H. Choi, M. Schmuth et al., "Basis for improved permeability barrier homeostasis induced by PPAR and LXR activators: liposensors stimulate lipid synthesis, lamellar body secretion, and post-secretory lipid processing," Journal of Investigative Dermatology, vol. 126, no. 2, pp. 386392, 2006.

[124] N. Y. Schurer and P. M. Elias, "The biochemistry and function of stratum corneum lipids." Advances in lipid research, vol. 24, pp. 27-56, 1991. 


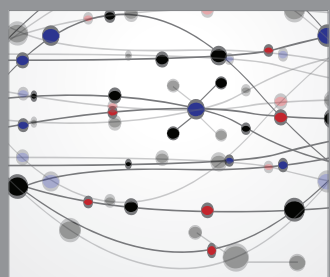

The Scientific World Journal
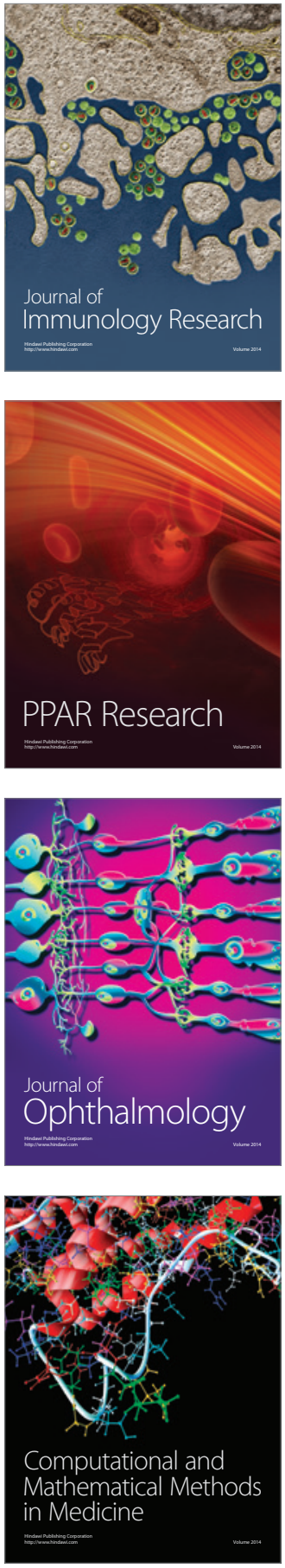

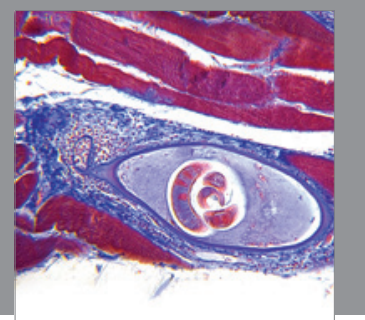

Gastroenterology

Research and Practice
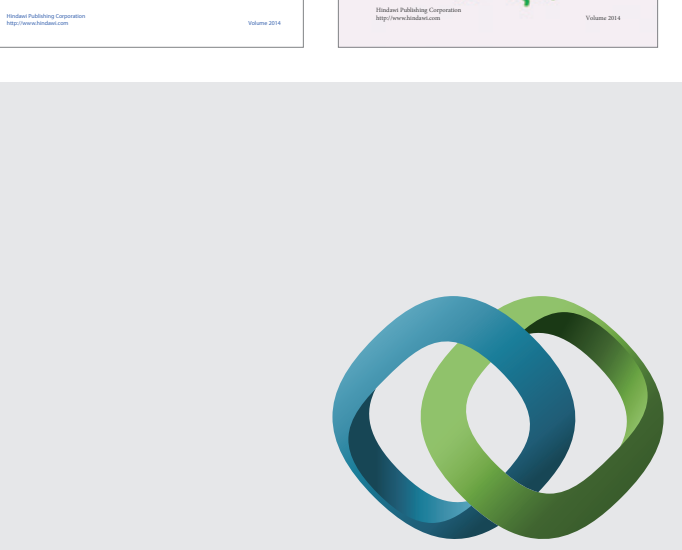

\section{Hindawi}

Submit your manuscripts at

http://www.hindawi.com
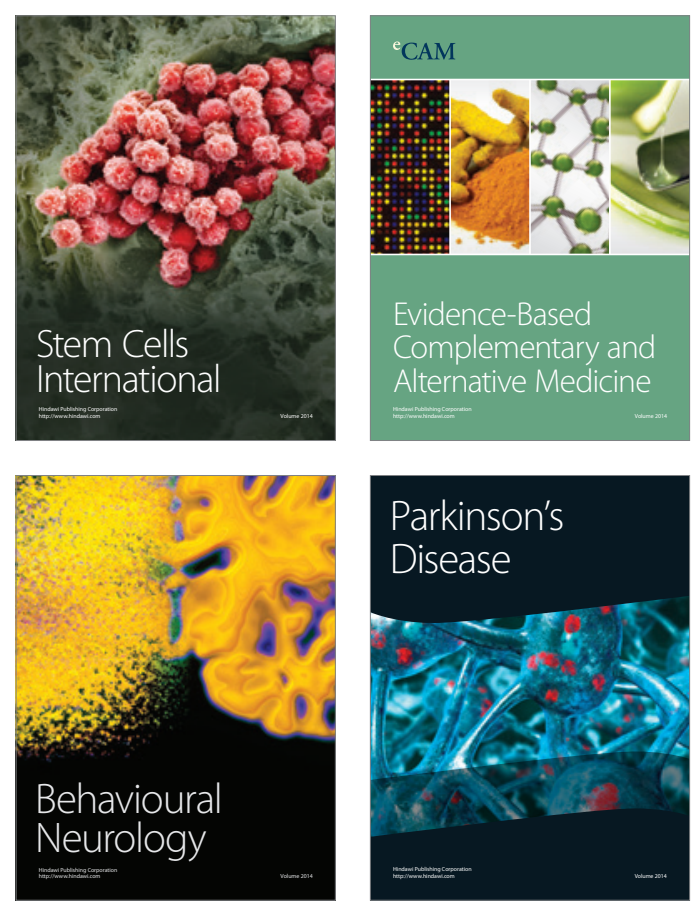

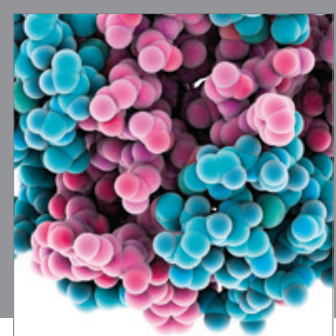

Journal of
Diabetes Research



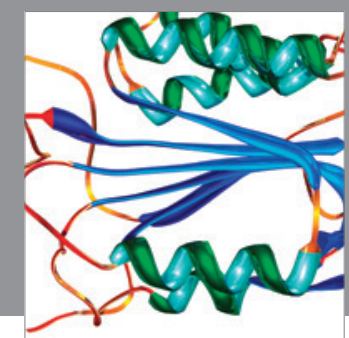

Disease Markers
